\title{
PEMANFAATAN KARDUS BEKAS SEBAGAI MEDIA PEMBELAJARAN UNTUK MEMPERKENALKAN TEMPAT IBADAH PADA ANAK USIA DINI
}

\author{
Rizkiya Fauziyah ${ }^{1}$
}

\begin{abstract}
ABSTRAK
Penggunaan media dalam proses pembelajaran dapat membangkitkan keinginankeinginan dan minat yang baru, membangkitkan motivasi, dan rangsangan kegiatan belajar, bahkan membawa pengaruh-pengaruh psikologis terhadap siswa khususnya siswa usia dini. Penggunaan media pembelajaran akan membantu keefektifan proses pembelajaran dan penyampaian pesan dan isi pelajaran. Media pembelajaran bermanfaat memperjelas penyampaian materi ajar, mengatasi ruang dan waktu, memacu anak untuk lebih aktif, dan dapat meningkatkan kerjasama. Adapun manfaat dari penggunaan suatu media pembelajaran akan dapat dirasakan secara optimal apabila guru mampu memilih dan menggunakan media tersebut sesuai dengan tujuan dan fungsinya. Media puzzle yang terbuat dari kardus yang tidak terpakai lagi merrupakn salah satu dari begitu banyaknya media yang bisa didapat dari lingkungan sekitar yang bermanfaat untuk pembelajaran pengenalan tempat beribadah pada anak usia dini. Selain bermanfaat bagi siswa media pembelajaran juga bermanfaat bagi pendidik. Pendidik juga akan mendapat keterampilan untuk merancang desain media pembelajaran, membuatnya, dan memelihara media pembelajaran dengan baik.
\end{abstract}

Kata Kunci: media pembelajaran, puzzle, kardus, pengenalan tempat ibadah.

\section{A. PENDAHULUAN}

Belajar bukan menghapal dan bukan pula mengingat. Belajar adalah suatu proses yang ditandai dengan adanya perubahan pada diri seseorang. Belajar yang menyenangkan (joyful learning) pada anak dapat menumbuhkembangkan keterampilan hidup (life skill) sejak dini sesuai dengan dasar-dasar perkembangan anak Untuk menunjang kebutuhan para anak-anak mendapatkan materi yang lebih mudah dan cepat di dapat tentunya lembaga harus menyiapkan media-media yang pas dan cocok untuk diterapkan pada anak-anak. . Sebagai sarana belajar maka pendidik harus menyiapkan alat/media yang tepat untuk menstimuli perkembangan anak.

Media memiliki kedudukan yang sangat penting dalam mencapai tujuan pembelajaran secara efektif. Nana Sudjana (1997) berpendapat bahwa sumber belajar segala daya yang dimanfaatkan guna memberi kemudahan kepada seseorang dalam belajarnya. Atau dalam proses pembelajaran baik secara langsung atau tidak langsung, sebagian atau secara keseluruhan.

Lingkungan belajar yang diatur oleh guru mencakup tujuan pembelajaran, bahan pembelajaran, metodologi pembelajaran, dan penilaian pembelajaran. Secara

1 Mahasiswa Sekolah Pascasarjana UPI 
khusus terkait metodologi pembelajaran, aspek ini terkait dengan dua hal yang saling menonjol yaitu metode dan media pembelajaran.

Media dalam proses pembelajaran dapat mempertinggi proses belajar siswa dalam pembelajaran yang pada gilirannya diharapkan dapat mempertinggi hasil belajar yang dicapainya. Berbagai penelitian yang dilakukan terhadap penggunaan media dalam pembelajaran sampai pada kesimpulan, bahwa proses dan hasil belajar pada siswa menunjukkan perbedaan yang signifikan antara pembelajaran tanpa media dengan pembelajaran menggunakan media. Oleh karena itu penggunaan media pembelajaran sangat dianjurkan untuk meningkatkan kualitas pembelajaran.

Peran media dalam pembelajaran khususnya dalam pendidikan anak usia dini semakin penting artinya mengingat perkembangan anak pada saat itu berada pada masa berfikir konkrit. Oleh karena itu salah satu prinsip pendidikan untuk anak usia dini harus berdasarkan realita artinya bahwa anak diharapkan dapat mempelajari sesuatu secara nyata. Dengan demikian dalam pendidikan untuk anak usia dini harus menggunakan sesuatu yang memungkinkan anak dapat belajar secara konkrit. Prinsip tersebut mengisyaratkan perlunya digunakan media sebagai saluran penyampai pesan-pesan pendidikan untuk anak usia dini.

Media yang akan dijelaskan saat ini yaitu penggunaan kardus bekas untuk menjelaskan pengenalan tempat ibadah pada anak usia dini. Pembelajaran ini bertema lingkungan dengan aspek perkembangan yang akan dicapai berupa pengenalan nilai-nilai moral dan agama. Pengenalan sejak dini tentang tempattempat beribadah akan membuat anak lebih dalam mengetahui tentang agama yang dianutnya, dari mulai menyebutkan jenis-jenis agama, meyebutkan tempat ibadah tiap-tiap agama yang ada di Indonesia.

Menurut Jean Piaget (seorang Psikolog dari Perancis), semua anak memiliki pola perkembangan kognisi yang sama, yaitu melalui empat tahapan : Sensori Motor, Pra - Operasional, Konkret - Operasional dan Formal Operasional. Perkembangan kognisi anak usia dini (2-7 tahun) berada pada tahapan berpikir "Pra operasional". Tahap Pra Operasional adalah tahap dimana anak tidak dapat memahami sesuatu tanpa dipraktekkan terlebih dahulu (Piaget, 1970).

Sejalan dengan pendapat Piaget, Jean Jacques Rousseau, mengatakan bahwa, "Anak usia dini belajar melalui aktivitas fisiknya." Dengan kata lain, untuk mengenalkan ajaran agama kepada anak usia dini, haruslah dengan cara memberikan kesempatan kepadanya untuk mempraktekkan apa yang kita katakan, dengan cara memberikan contoh kepada anak bagaimana melakukannya. Salah satu caranya yaitu dengan mengunjungi tempat ibadah

Kardus bekas merupakan sampah yang bisa ditemukan di lingkungan sekitar anak. Melalui bantuan orang tua, anak-anak dapat dengan mudah menemukan kardus yang akan digunakan untuk media pembelajaran. Ini sesuai dengan pembelajran konstektual dimana anak bisa memanfaatkan benda yang ada di lungkungna sekitar mereka. Pemanfaatan kardus juga sesuai dengan prinsip recycle dalam kecerdasan ekologis dimana kita dapat mendaur ulang sampah yang ada di sekitar kita menjadi sesuatu yang bermanfaat. Kontetks kita sebagai pendidik anakanak kita juga harus cerdas memilih benda yang akan dijadikan media pembelajaran, yaitu benda yang tidak berbahaya ketika digunakan oleh ana-anak. Memilih media 
yang mudah di dapat anak dan tidak membutuhkan biaya yang berlebihan agar anak mendapatkan pembelajaran yang bermakna.

Seorang guru pada saat menyajikan informasi kepada anak usia dini harus menggunakan media agar informasi tersebut dapat diterima atau diserap anak dengan baik dan pada akhirnya diharapkan terjadi perubahan-perubahan perilaku berupa kemampuan-kemampuan dalam hal pengetahuan, sikap, dan keterampilannya. Sesuai dengan pernyataan ini maka penggunaan media kardus bekas dalam pengenalan tempat ibadah kepada anak usia dini dapat kita terapkan dalam pembelajaran.

\section{B. PEMBAHASAN}

\section{Konsep Media Pembelajaran}

Untuk dapat memahami apakah media pendidikan itu, akan diillustrasikan cerita sebagai berikut: Ibu Winda adalah guru yang sedang mengajarkan kemampuan dasar keterampilan. Dalam penjelasannya, Ibu Winda meminta agar anak didik menggunakan beberapa potongan korek api untuk mereka gunakan dalam membuat bentuk-bentuk geometri. Selain itu, Ibu Winda juga menyediakan lem dan buku gambar yang digunakan anak didik untuk menunjang aktivitas tersebut.

Dalam cerita tersebut yang dimaksud dengan media adalah potongan korek api, sedangkan lem dan buku gambar adalah alat pelajaran untuk pelajaran keterampilan. Suryo Subroto (1984) mengungkapkan bahwa media merupakan bagian dari sumber pengajaran yang digunakan sebagai perantara dalam proses belajar mengajar untuk mempertinggi efektivitas dan efisiensi dalam mencapai tujuan pendidikan.

Kata media berasal dari bahasa Latin dan merupakan bentuk jamak dari kata medium yang berarti perantara atau pengantar. Secara umum, media diartikan sebagai perantara atau pengantar pesan dari pengirim ke penerima pesan. Berikut ini beberapa pendapat ahli pendidikan mengenai media, yaitu:

a. Menurut Briggs (1970), media adalah segala alat fisik yang dapat menyajikan pesan serta perangsang peserta didik untuk belajar.

b. Menurut Assosiasi Nasional (National Education Association/NEA), media adalah bentuk-bentuk komunikasi baik tercetak maupun audiovisual serta peralatannya, dan media hendaknya dapat disiasati, dilihat, didengar dan dibaca.

c. Menurut Gagne dan Reiser (1983), media pendidikan atau pengajaran adalah alat-alat fisik di mana pesan-pesan instruksional dikomunikasikan.

d. Dinje Borman Rumumpuk, mendefinisikan media pendidikan adalah setiap alat, baik software maupun hardware yang dipergunakan sebagai media komunikasi dan bertujuan untuk meningkatkan efektivitas proses belajar mengajar.

Dalam Undang-Undang Republik Indonesia Nomor 20 Tahun 2003 tentang Sistem Pendidikan Nasional Bab I Pasal 1 ayat 1 dijelaskan bahwa Pendidikan adalah usaha sadar dan terencana untuk mewujudkan suasana belajar dan proses pembelajaran agar peserta didik secara aktif mengembangkan potensi dirinya untuk memiliki kekuatan spiritual keagamaan, pengendalian diri, kepribadian, kecerdasan, 
akhlak mulia, serta keterampilan yang diperlukan dirinya, masyarakat, bangsa dan negara.

Dari uraian di atas, dapat dibuat kesimpulan bahwa media pendidikan atau pengajaran adalah segala alat pengajaran yang digunakan sebagai perantara untuk menyampaikan bahan-bahan pelajaran dalam proses belajar mengajar serta dapat merangsang pikiran, perhatian, dan minat anak didik sehingga memudahkan pencapaian tujuan pendidikan atau pengajaran tersebut.

Dari beberapa pendapat di atas tentang pengertian media pendidikan, dapat dilihat tujuan dari penggunaan suatu media ialah membantu pendidik menyampaikan bahan pelajaran secara lebih mudah kepada anak didik sehingga anak didik dapat memahami bahan pelajaran tersebut. Secara umum media pendidikan digunakan dengan tujuan sebagai berikut:

a. Dengan menggunakan media pendidikan, pendidik dapat memperjelas penyampaian bahan pelajaran sehingga mengurangi verbalitas (baik dalam bentuk kata-kata atau tulisan).

b. Dengan menggunakan media pendidikan, pendidik dapat mengatasi ruang dan waktu, misalnya mempelajari kebudayaan suatu negara dapat digunakan film dan buku cetakan.

c. Memberikan kemudahan dan pengalaman belajar sehingga merangsang minat belajar anak didik karena proses pembelajaran lebih bervariasi.

d. Dengan penggunaan media pendidikan secara tepat dan bervariasi, pendidik dapat mengatasi sifat pasif pada anak didik menjadi lebih aktif dalam proses belajar mengajar di kelas.

e. Dengan penggunaan media pendidikan di dalam kelas ataupun di lingkungan sekolah diharapkan mendorong munculnya kerjasama pada anak didik.

Adapun fungsi penggunaan media pendidikan menurut beberapa ahli adalah sebagai berikut.

a. Derek Rowntrie berpendapat bahwa fungsi media pendidikan sebagai berikut:

1) Engange the studeent's motivation (membangkitkan motivasi belajar)

2) Recall earlier learning (mengulang apa yang dipelajari)

3) Provide new learning stimuli (menyediakan stimuli belajar)

4) Activate student's response (mengaktifkan respon anak didik)

5) Active speedy feedback (memberikan balikan dengan cepat/segera

6) Encourage appropriate practice (menggalakkan latihan yang serasi).

b. Levie \& Lentz (1982) mengemukakan fungsi media pendidikan khususnya media visual, adalah:

1) Fungsi Atensi (menarik dan mengarahkan perhatian siswa)

2) Fungsi Afektif (dapat mengugah emosi dan sikap siswa)

3) Fungsi Kognitif (memperlancar pemahaman siswa)

4) Fungsi Kompensatoris (dapat mengakomodasi pemahaman siswa yang lemah dalam belajar)

adalah:

Dengan pendapat tersebut di atas, dapat dikatakan fungsi media pendidikan

a. Media pendidikan merupakan alat bantu mengajar untuk mewujudkan situasi belajar yang efektif dan efisien. 
b. Dapat membangkitkan motivasi belajar anak didik.

c. Media pendidikan merupakan bagian integral dari keseluruhan kegiatan dan situasi belajar mengajar.

Keragaman dan jenis media yang dapat dimanfaatkan dalam pembelajaran sangat banyak dan variatif oleh karena itu dalam perkembangannya timbul usahausaha untuk mengelompokkan dan mengklasifikasi media-media tersebut menurut kesamaan ciri atau karakteristiknya. Para ahli yang tercatat dalam proses pengkalifikasian tersebut antara lain: Rudy Bretz, Duncan, Briggs, Gagne, Edling, Schramm, Allen, dan lain-lain. Namun demikian dari beberapa pengelompokkan media yang mereka lakukan belum terdapat suatu kesepakatan tentang klasifikasi atau taksonomi media yang berlaku umum dan mencakup segala aspeknya, khususnya untuk suatu sistem pembelajaran. Bahkan tampaknya memang tidak pernah akan ada sistem pengelompokkan yang sahih dan berlaku umum. Berkaitan dengan hal tersebut, dalam bahan ajar ini jenis media tersebut akan dibagi menjadi tiga kelompok besar sebagaimana yang digambarkan dalam bagan berikut.

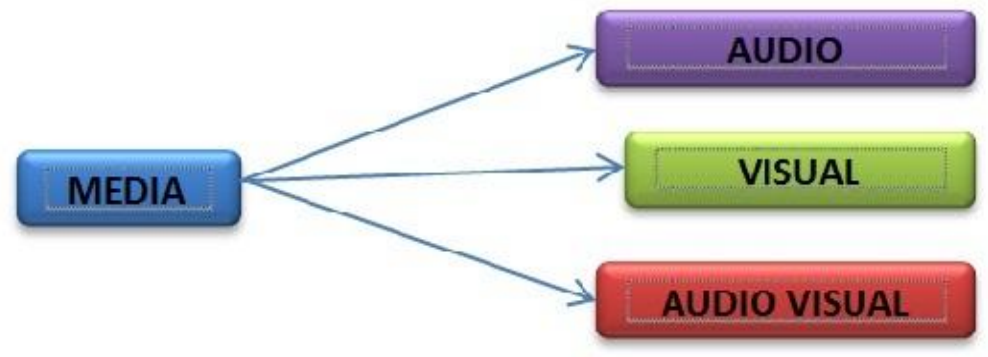

\section{Gambar 1}

\section{Jenis- Jenis Media Pembelajaran}

Dari bagan di atas, kita dapat melihat bahwa media pendidikan dapat dikelompokkaN menjadi tiga bagian, yaitu media visual, media audio, dan media audio-visual.

Sebelum memutuskan untuk menggunakan media pendidikan tertentu dalam suatu pengajaran, seorang pendidik perlu memahami prinsip-prinsip atau faktorfaktor yang harus dipertimbangkan dalam pemilihan suatu media. Adapun prinsipprinsip pemilihan media tersebut, yaitu:

a. Memilih media harus berdasarkan tujuan dan bahan pengajaran yang akan disampaikan.

b. Memilih media harus disesuaikan dengan perkembangan anak didik.

c. Memilih media harus disesuaikan dengan kemampuan pendidik, baik dalam pengadaannya dan penggunaannya.

d. Memilih media harus disesuaikan dengan situasi dan kondisi atau pada waktu, tempat dan situasi yang tepat.

e. Memilih media harus disesuaikan dengan kemampuan lembaga pendidikan dari segi pendanaan dan pengadaan 
Tahap pembuatan dapat dikatakan sebagai puncak dari tahap-tahap lain dalam pengembangan media. Dalam pembuatan media pembelajaran ini ada beberapa prinsip yang harus diperhatikan .

a. Media pembelajaran yang dibuat hendaknya multi guna.

b. Bahan mudah didapat di lingkungan sekitar lembaga PAUD dan murah atau bisa dibuat dari bahan bekas/sisa.

c. Tidak menggunakan bahan yang berbahaya bagi anak.

d. Dapat menimbulkan kreativitas, dapat dimainkan sehingga menambah kesenangan bagi anak, menimbulkan daya khayal dan daya imajinasi serta dapat digunakan untuk bereksperimen dan bereksplorasi.

e. Sesuai dengan tujuan dan fungsi sarana.

f. Dapat digunakan secara individual, kelompok, dan klasikal.

g. Dibuat sesuai dengan tingkat perkembangan anak.

Adapun kegiatan yang perlu dilakukan setelah mengetahui prinsip- prinsip pembuatan media. Guru harus membuat rancangan atau desai media pembelajaran. Di bawah ini adalah contoh rancangan media pembelajaran.

\begin{tabular}{|c|c|}
\hline Nama Media & : ....................................... \\
\hline Sasaran & 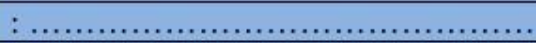 \\
\hline $\begin{array}{l}\text { Kemampuan yang } \\
\text { dikembangkan }\end{array}$ & 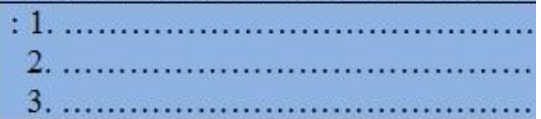 \\
\hline Bahan dan Alat & 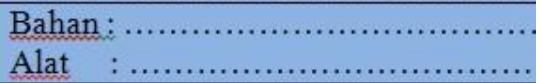 \\
\hline Cara Membuat & 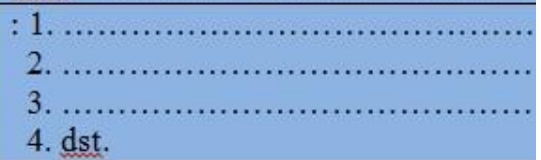 \\
\hline Cara Menggunakan & 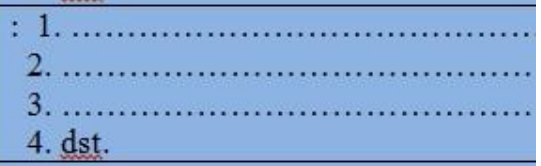 \\
\hline Gambar Desain & \\
\hline
\end{tabular}

Gambar 2.2

Desain Pembuatan Media Pembelajaran

Menyimpan dan memelihara media pembelajaran di lembaga PAUD baik yang ada di dalam ruangan maupun yang ada di luar merupakan hal yang penting dilakukan oleh guru. Hal tersebut dikarenakan penggunaan media pembelajaran tersebut tentu tidak hanya untuk satu kali kegiatan belajar saja melainkan akan digunakan secara terus-menerus. Selain itu intensitas penggunaan media pembelajaran oleh anak juga akan sangat tinggi. Apalagi untuk media-media pembelajaran tertentu yang sangat disukai oleh anak. Sehubungan dengan pentingnya fungsi penyimpanan dan pemeliharaan ini, guru harus mengetahui jenis media pembelajaran yang perlu disimpan dan dipelihara dengan baik. Cara anak meletakkan media pembelajaran di kelas tidak terlepas dari pengawasan guru. Guru juga harus memantau bagaimana cara anak memainkan media tersebut dan 
mengembalikan media tersebut pada tempatnya, karena anak harus dibiasakan bertanggungjawab terhadap media pembelajaran yang dimainkannya.

Evaluasi merupakan bagian penting dalam pengembangan media pembelajaran. Apapun juga media yang dibuat perlu dinilai terlebih dahulu sebelum digunakan secara luas. Evaluasi itu ini dimaksudkan untuk mengetahui apakah media yang dibuat tersebut dapat mencapai tujuan-tujuan yang telah ditetapkan atau tidak. Hal ini penting untuk diingat dan dilakukan karena banyak orang beranggapan bahwa sekali mereka membuat media pasti seratus persen ditanggung baik. Anggapan itu sendiri tidaklah keliru karena sebagai pengembang media secara tidak langsung telah menurunkan hipotesis bahwa media yang dibuat tersebut dapat memberikan hasil belajar yang lebih baik. Hipotesis tersebut perlu dibuktikan dengan mengujicobakannya ke sasaran yang dimaksud.

Prosedur atau tahapan evaluasi media terkait dengan bagaimana langkahlangkah yang dilakukan dalam mengevaluasi media yang telah dibuat. Sekali lagi perlu ditegaskan bahwa dengan evaluasi ini diharapkan hasil media yang dibuat terjamin keandalannya. Langkah atau tahapan evaluasi media yang dapat ditempuh terdiri dari tahap evaluasi satu lawan satu (one to one), evaluasi kelompok kecil (small group evaluation), dan evaluasi lapangan (field evaluation).

\section{Pembuatan Puzzle dari Kardus Bekas}

Kardus bekas dapat digunakan sebagai media pembelajaran anak usia dini. Adapun Langkah- Langkah pembuatan Puzzle dari Kardus Bekas adalah sebagai berikut.

\begin{tabular}{|c|c|}
\hline Nama Media & Puzzle Masjid \\
\hline Sasaran & Anak usia dini \\
\hline $\begin{array}{l}\text { Kemampuan yang } \\
\text { dikembangkan }\end{array}$ & $\begin{array}{l}\text { 1. Mengenal bentuk-bentuk yang tak beraturan } \\
\text { 2. Melatih daya pengamatan dan konsentrasi } \\
\text { 3. Melatih menguraikan dan menyatukan kembali pada bentuk } \\
\text { 4. Mengenalkan tempat beribadah pada anak sejak dini }\end{array}$ \\
\hline Bahan dan alat & 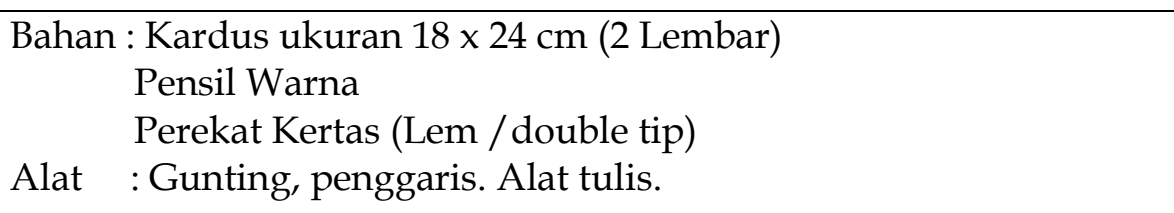 \\
\hline Cara membuat & $\begin{array}{l}\text { 1. Dua buah kardus dipotonmg dengan ukuran yang sama } \\
\text { 2. Satu bagian dibuat gambar "Masjid" } \\
\text { 3. Warnai Gambar tersebut } \\
\text { 4. Potong gambar menjadi } 10 \text { keping } \\
\text { 5. Kardus lainnya direkatkan menggunkan lem } \\
\text { 6. Susun pootongan-potongan menjadi gambar yang utuh. }\end{array}$ \\
\hline $\begin{array}{l}\text { Cara } \\
\text { Menggunakan }\end{array}$ & $\begin{array}{l}\text { 1. Memperlihatkan gambar puzzle sebagai kesatuan lalu } \\
\text { mengeluarkan gambar-gambar tersebut menjadi bagian- } \\
\text { bagian. } \\
\text { 2. Menyusun kembali gambar itu disesuaikan dengan lekuk- } \\
\text { lekuk yang sudah ada di kardus dasar }\end{array}$ \\
\hline
\end{tabular}




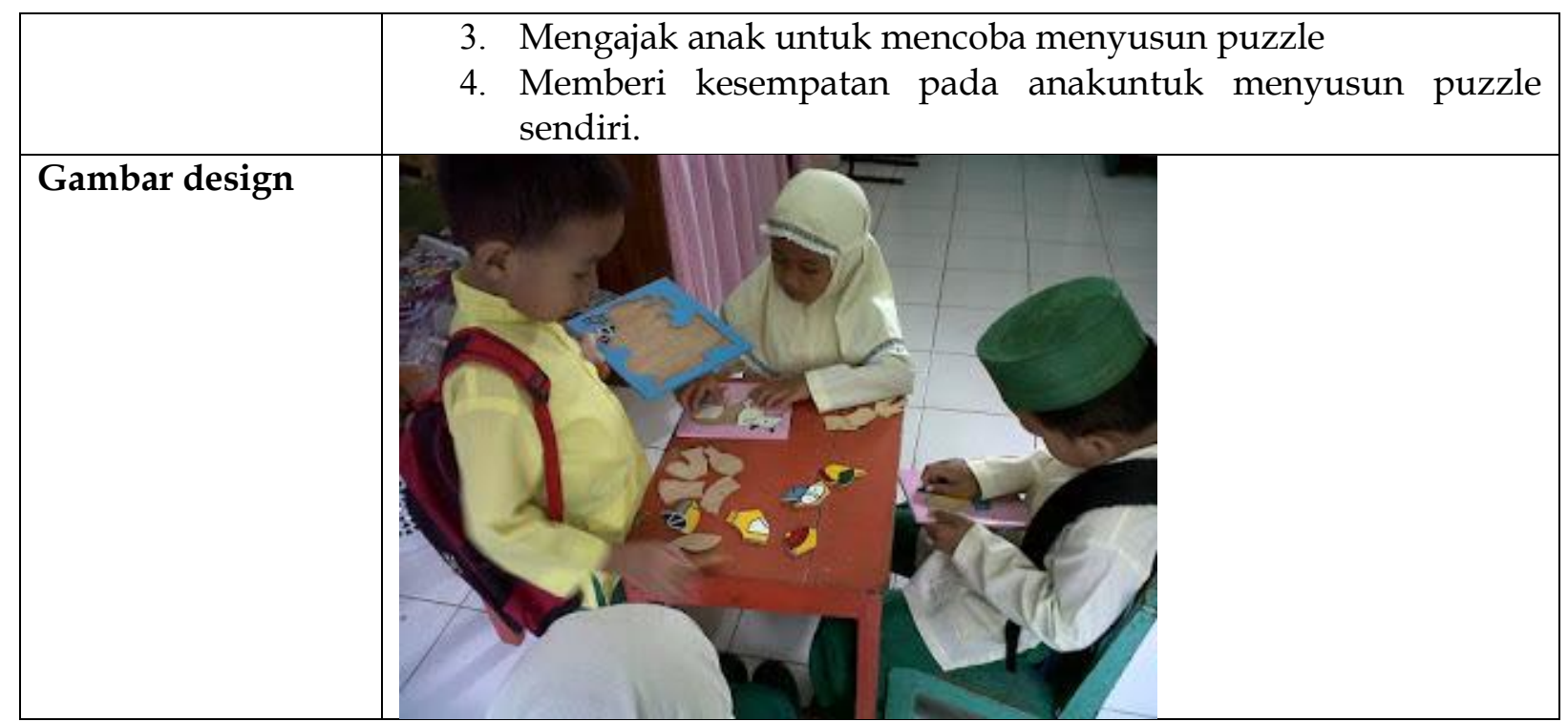

Tabel 2

Table Design Media Pembelajaran

\section{PENUTUP}

Sebenarnya banyak media belajar yang berada di lingkungan sekitar yang dapat digunakan, namun hal itu sering terlupakan. Betapapun kecil atau terpencil suatu sekolah dan betapapun ketidakmampuan suatu sekolah, sekurang-kurangnya sekolah mempunyai sumber belajar yang dapat dimanfaatkan untuk memperlancar proses belajar mengajar.

Media pembelajaran merupakan salah satu strategi yang efektif dalam pembelajaran. Media puzzle yang terbuat dari kardus bekas untuk memperkenalkan tempat beribadah adalah salah satu media pembelajaran yang edukatif dan sesuai dengan aspek perkembangan anak yang tidak menyalahi prinsip-prinsip pemilihan media pembelajaran agar berdampak positif bagi anak, baik dari segi kognitif, afektif, psikomotorik untuk meningkatkan life skill mereka. Proses pembelajaran menjadi lebih bermakna dan siswa pun merasa lebih bergembira dalam menerima pelajaran. Cara pembuatan yang sederhana pun akan membuat para guru tidak terlalu sulit dalam membimbing siswa dalam proses pemilihan, pembuatan, dan pemeliharaannya.

\section{DAFTAR PUSTAKA}

Depdikbud, 1988), hal. 17.Undang-Undang Republik Indonesia Nomor 20 Tahun 2003

Nana Sudjana dan Ahmad Rivai. (1991). Media Pengajaran. Bandung: Sinar Baru.

PUSTAKA ONLINE : Diakses pada hari Kamis, 05.00 s.d. 10.44

http://melyloelhabox.blogspot.com/2012/12/mengenalkan-agama-padaanak_21.html

http://arenapaud.blogspot.com/2011/07/media-pengajaran.html http://neninopela.blogspot.com/2013/05/makalah-media-pembelajaran.html 